\title{
THE DEVELOPMENT OF MEDIA SCRAPBOOK ON ANY MATERIAL A VIRUS TO BASICALLY INCREASED THE MOTIVATION TO STUDY A STUDENT OF SENIOR HIGH SCHOOL CLASS $X$
}

\author{
Syafiatul khusna ${ }^{1}$ ), eva nurul malahayati $\left.{ }^{2}\right)$, dwi kameluh agustina ${ }^{2}$ ) \\ Eka Apriliatul Qoidah ${ }^{1)}$, Dian Puspita Anggraini ${ }^{2}{ }^{2}$, Maratus Sholihah ${ }^{3)}$ \\ ${ }^{1,2}$ Islamic University of Balitar; Jl. Majapahit No.04, Telp. (0342) 813145 \\ ${ }_{3}^{3} J u r u s a n$ Pendidikan Biologi, FKIP Universitas Islam Balitar, Blitar \\ e-mail: ${ }^{* 1}$ syafiatul30 @ gmail.com. ${ }^{2}$ dianpuspitaanggraini @unisbablitar.ac.id, \\ ${ }^{3}$ maratus maratussholihah @unisbablitar.ac.id
}

\begin{abstract}
This research aim to know the properness of scrapbook media on virus material and to increase student learning motivation after using scrapbook media for the tenth grade of senior high school. This research is Research and Development (RnD) by applying the Borg and Gall development model which is limited to the seventh stage. Data were analyzed by qualitative descriptive analysis. The average rating by experts is $80.06 \%$ with eligible criteria. The increasing student learning motivation was $19.21 \%$. Based on the results of the study it can be concluded that scrapbook media on virus material for the tenth grade of senior high school is proper to be used in learning process and increase student learning motivation.
\end{abstract}

Keywords : Research and Development, scrapbook, learning motivation

\section{INTRODUCTION}

The implementation of the curriculum 2013 aims to prepare Indonesia so that humans have the ability to live the faith, productive, able to think critically, creatively and innovative and affective as well as being able to contribute to the life of the of society, nation and State. The role of the teacher is crucial to achieve those goals. The teacher in this case is claimed to be able to provide an innovative and creative learning with the hope that students can achieve the learning objectives in accordance with the curriculum of 2013.

One of the interesting and unique mediums to be used is the scrapbook media. Media Scrapbook is a sheet of paper containing the book folded and accompanied by pictures and learning materials that are decorated with creative. Scrapbook considered have attraction for students because it is able to present the visualization with forms created 
with fold, move and appear so give the surprise and admiration for students when it opens every courtyard (Khoiraton. 2014). In addition, the scrapbook media can overcome the limitations of our observations. Materials to make a scapbook easily obtainable, without using special equipment. In addition, Scrapbook media can also provide special experiences on students because it involves the activities of students such as sliding, folding parts open, and Scrapbook. This will create its own impression to the reader so it will be easier to fit into memory when using this media (Setyawan, 2014).

The material of the virus is one of the subject matter taught in biology class $x$. virus Material in need of sample images and creative learning experiences that related characteristics of the virus, a form of the virus and the role of viruses in real life because of the size of the virus the microscopic, so to see and study the viruses needed tool in the form of electron microscopy. Therefore learning in class to the material the virus tend to be abstract and verbalitas. Perception abstract is here associated with the understanding of ideas, concepts and quality that can not be seen so that the required media supporting learning so that students do not get tired of viruses, able to achieve learning objectives as well as can help in increasing motivation and student learning outcomes.

Based on its field observation through interviews and the survey to students and teachers shows that learning biology to the matter of the virus in the school teacher use lks, the picture, charts and video telecast using related virus Icd structure, ciri-ciri virus, the viruses and replication of the virus. To the matter this virus students tend to bored study it because it has studied material invisible and students less motivated to study.As a result the motivation to study students still low.Teachers biology need media learning that would facilitate students to study matter biology.

Therefore, researchers can develop scrapbook media learning on learning Biology class X. Some of the research on the development of 
Scrapbook media has been conducted by Princess (2014), Sirojudin (2014), Pepen (2015) Syahriyanti (2016) and Sari (2017), obtained results media scrapbook and the feasibility of the media by a few validator obtained very good results. This shows that the scrapbook media worthy for use in learning. The highly effective learning media to use and can improve cognitive outcomes students (cider, 2017). This is evidenced by the assessment by experts with the criteria as well as the results of the response of teachers and students through trials with criteria very well. Based on the description above, this research aims to develop learning material on scrapbook media virus. Another goal of this research is to know the improvement of student learning motivation of the use of learning scrapbook media.

\section{METHOD RESEARCH}

The kind of research that is used is research and development ( $R$ \& D ) with a model research Borg and Gall .Research model Borg and Gall to seven that is done to the stages of data collection, planning, early design products, validation, the revision, the trial of a limited, and the revision of due to limited time, and the cost of energy.

The subject of this study is a student X SMAN Kademangan. At the development of scrapbook media virus material used as the subject of the trial is the media, the matter and linguist.The data collected in the form of qualitative and quantitative data.An instrument data collection the survey validation expert who used to know eligibility a by product 3 experts matter, 3 experts media and 3 the linguist.An instrument survey motivation to know the influence of media uses scrapbook against the motivation to study students consisting of 22 a statement and analyzed a sort of descriptive set. Scrapbook media learning applied in class with the design one group pretets postest.The media criteria feasibility scrapbook seen in Table 1. 
JOSAR, Vol. 1 No. 1 March, 2018; p-ISSN: 2502-8251; e-ISSN: 2503-1155

Copyrights@ Balitar Islamic University, Blitar-Indonesia

https://ejournal.unisbablitar.ac.id/index.php/josar

Tabel 1 The level of the feasibility level

\begin{tabular}{ll}
\hline Presentase penilaian validator & Kriteria kualitatif \\
\hline $80 \%<x \leq 100 \%$ & Very whorthy \\
$60 \%<x \leq 80 \%$ & Worthy \\
$40 \%<x \leq 60 \%$ & Quite worthy \\
$20 \%<x \leq 40 \%$ & Less worthy \\
$0 \%<x \leq 20 \%$ & Very less worthy \\
\hline
\end{tabular}

\section{RESULTS AND DISCUSSION}

The feasibility of the learning scrapbook media on the subjects of biology viral material is applied to the class X SMA/MA is known based on the assessment by experts/validator.

The results of the assessment of the feasibility of aspects of the content of the material and the presentation of the material can be seen in table 2.

Tabel 2 The assessment results of the scrapbook media by material experts

\begin{tabular}{lllll}
\hline Statement & Experts & Experts & Experts & Score total \\
\hline \multirow{4}{*}{ Fill the material } & $\mathbf{1}$ & $\mathbf{2}$ & $\mathbf{3}$ & \\
\cline { 2 - 5 } & 5 & 4 & 5 & 14 \\
\hline \multirow{4}{*}{ Precentation aspect } & 5 & 4 & 4 & 13 \\
\cline { 2 - 5 } & 5 & 3 & 5 & 15 \\
\cline { 2 - 5 } & 5 & 3 & 4 & 12 \\
\cline { 2 - 5 } & 5 & 4 & 4 & 12 \\
\cline { 2 - 5 } & 5 & 4 & 3 & 13 \\
\hline Total & 5 & 2 & 4 & 13 \\
\hline Criterion score & & & 4 & 13 \\
\hline Average precentage & & & & 127 \\
\hline
\end{tabular}

Based on table 2 assessments by 3 people of the matter have the average the percentage of $84.6 \%$ were categorized as it is very appropriate, this scrapbook media to the matter of the components in the 
virus kept on a constant review the eligibility of the contents of / material be classified as good. Based on the criteria expressed have been very feasibility share in the feasibility. The scope of matter in a scrapbook media is in accordance with $\mathrm{ki}$ and $\mathrm{kd} 2013$ curriculum. Content material in a scrapbook media talk about material of the virus and general knowledge about the virus.Students will be is easier to understand a concept certain when explanation started from that is easily or something concrete , something that is real in their settings (Depdiknas, 2008 ).

The discussion material meet the aspect of completeness of the traits of a virus, the structure of the body the virus, replication of the virus and the role of life, and a virus in would motivate students in learning. The presentation of the contents of the / material are easy to understand and familiar with students.The figures which there are in a media have been of the overwhelming of pictures and source of a picture and the presentation of material is in accordance with the development of the science of biology .This is in accordance with the criteria for the selection with media according to sardiman in 2008 that the use of the media can clarify a message verbalistis / information so that i do not only in the form of words or writings ), but in the form of the figure. The assessment results of the by media experts can be seen in table 3 .

Table 3 The assessment results of the scrapbook media by media experts

\begin{tabular}{lllll}
\hline \multicolumn{1}{c}{ Statement } & Experts 1 & Experts 2 & Experts 3 $\begin{array}{l}\text { Score } \\
\text { total }\end{array}$ \\
\hline \multirow{2}{*}{$\begin{array}{l}\text { Physical condition } \\
\text { of the book }\end{array}$} & 4 & 4 & 5 & 13 \\
\cline { 2 - 5 } & 4 & 4 & 4 & 12 \\
\cline { 2 - 5 } & 5 & 4 & 4 & 13 \\
\hline \multirow{2}{*}{$\begin{array}{l}\text { Letters used } \\
\text { Image clarity and } \\
\text { image layout } \\
\text { selection }\end{array}$} & 4 & 4 & 4 & 11 \\
\cline { 2 - 5 } & 5 & 4 & 3 & 11 \\
\cline { 2 - 5 } & 4 & 4 & 4 & 12 \\
\hline
\end{tabular}


JOSAR, Vol. 1 No. 1 March, 2018; p-ISSN: 2502-8251; e-ISSN: 2503-1155

Copyrights@ Balitar Islamic University, Blitar-Indonesia

https://ejournal.unisbablitar.ac.id/index.php/josar

\begin{tabular}{|c|c|c|c|c|}
\hline & 4 & 4 & 4 & 12 \\
\hline & 3 & 4 & 4 & 11 \\
\hline \multirow{2}{*}{ Color section } & 3 & 4 & 4 & 11 \\
\hline & 3 & 4 & 4 & 11 \\
\hline \multirow{5}{*}{$\begin{array}{l}\text { Compilation } \\
\text { content section }\end{array}$} & 4 & 4 & 4 & 12 \\
\hline & 4 & 4 & 3 & 11 \\
\hline & 5 & 4 & 3 & 12 \\
\hline & 4 & 4 & 3 & 11 \\
\hline & 4 & 4 & 5 & 13 \\
\hline Total & 69 & 72 & 69 & 210 \\
\hline \multicolumn{4}{|l|}{ Criterion score } & 270 \\
\hline \multicolumn{4}{|c|}{ Average precentage } & $77,8 \%$ \\
\hline
\end{tabular}

Based on the table 3 scores of 3 media experts have rata-rata the percentage of $77,8 \%$ category in a worthy, with its media scrapbook in terms of the presentation of said worth .Based on the criteria eligibility expressed have been very according to the feasibility. The scrapbook which has developed are ready to use by the experiment field .Media can be used as as an intermediary / distributor information from the sender to the receiver, from teachers to students ( usman , 2002 ) .Media has increased good can be used in learning .Scores scrapbook by the media languages can be seen in table 4 .

Table 4 Scores scrapbook by media linguist

\begin{tabular}{lllll}
\hline \multicolumn{1}{c}{ Statement } & Experts & Experts & Experts & Score total \\
\hline \multirow{3}{*}{ Language aspect } & $\mathbf{1}$ & $\mathbf{2}$ & $\mathbf{3}$ & 12 \\
\cline { 2 - 5 } & 3 & 4 & 4 & 10 \\
\cline { 2 - 5 } & $\mathbf{4}$ & 5 & 3 & 13 \\
\hline Total & & & & 35 \\
\hline Criterion score & & & 45 \\
\hline Average precentage & & & $77,8 \%$ \\
\hline
\end{tabular}

Based on the data in table 4 the assessment results of the of 3 a linguist obtain the average the percentage of $77,8 \%$ ) were categorized as worthy of , thus scrapbook media to the matter of the components in the virus kept on a constant review kebahasaan it is said worthy of for use 
.Based on the criteria into account the feasibility of expressed these forms of media is in accordance with the requirements into account the feasibility of .Language used in media scrapbook raw use of language that has been adjusted to their level of understanding and development of students . Language used can be digested by the students as well as can be imagined in imaginative by students about material a virus that are being studied.This is in accordance with the theory of usman ( 2002 ), who said that the media can visual lessons for students from can ease the concept of complex and abstract easier conceivable and understood.

Obtained the average keterbacaan testing shows the percentage of $89,23 \%$ which means that it is in the category of it is very appropriate media scrapbook on any material the virus have keterbacaan who it is very appropriate for students. For the complete transcript keterbacaan testing shows can be seen in table 5 . Table 5 scores scrapbook media by the experiment keterbacaan students

\begin{tabular}{|c|c|c|c|c|c|c|}
\hline \multirow[b]{2}{*}{$\begin{array}{l}\text { Stateme } \\
\text { nt }\end{array}$} & \multicolumn{5}{|c|}{ Penilaian } & \multirow{2}{*}{$\begin{array}{c}\text { Scor } \\
e \\
\text { total }\end{array}$} \\
\hline & $\begin{array}{l}\text { Stude } \\
\text { nt } 1\end{array}$ & $\begin{array}{l}\text { Stude } \\
\text { nt } 2\end{array}$ & $\begin{array}{l}\text { Stude } \\
\text { nt } 3\end{array}$ & $\begin{array}{l}\text { Stude } \\
\text { nt } 4\end{array}$ & $\begin{array}{l}\text { Stude } \\
\text { nt } 5\end{array}$ & \\
\hline \multirow{5}{*}{$\begin{array}{l}\text { Cakupan } \\
\text { materi }\end{array}$} & 4 & 4 & 4 & 4 & 4 & 20 \\
\hline & 4 & 5 & 5 & 5 & 4 & 23 \\
\hline & 5 & 5 & 4 & 4 & 5 & 23 \\
\hline & 4 & 4 & 5 & 5 & 4 & 22 \\
\hline & 5 & 5 & 4 & 4 & 5 & 23 \\
\hline \multirow{5}{*}{$\begin{array}{l}\text { Grafis } \\
\text { design }\end{array}$} & 4 & 5 & 4 & 5 & 5 & 23 \\
\hline & 5 & 4 & 5 & 5 & 4 & 23 \\
\hline & 4 & 5 & 5 & 4 & 5 & 23 \\
\hline & 5 & 4 & 4 & 5 & 4 & 22 \\
\hline & 5 & 5 & 5 & 4 & 5 & 24 \\
\hline \multirow{3}{*}{ Laguage } & 4 & 4 & 4 & 5 & 4 & 21 \\
\hline & 4 & 5 & 5 & 5 & 4 & 23 \\
\hline & 4 & 4 & 4 & 4 & 4 & 20 \\
\hline \multicolumn{7}{|l|}{ Total } \\
\hline \multicolumn{6}{|c|}{ Criterion score } & 325 \\
\hline Average $k$ & ecentag & & & & & 89,23 \\
\hline
\end{tabular}


JOSAR, Vol. 1 No. 1 March, 2018; p-ISSN: 2502-8251; e-ISSN: 2503-1155

Copyrights@ Balitar Islamic University, Blitar-Indonesia

https://ejournal.unisbablitar.ac.id/index.php/josar

The results of response on the use of such students scrapbook media can be seen in table 6 . Table 6 the results of students against scrapbook media response

\begin{tabular}{lll}
\hline No. & Statement & Score \\
\hline 1 & 1 & 131 \\
\hline 2 & 2 & 134 \\
\hline 3 & 3 & 132 \\
\hline 4 & 4 & 123 \\
\hline 5 & 5 & 132 \\
\hline 6 & 6 & 139 \\
\hline 7 & 7 & 135 \\
\hline 8 & 8 & 138 \\
\hline 9 & 9 & 136 \\
\hline 10 & 10 & 136 \\
\hline 11 & 11 & 138 \\
\hline 12 & 12 & 131 \\
\hline 13 & 13 & 129 \\
\hline 14 & 14 & 119 \\
\hline Total & 1853 \\
\hline Criterion score & 2100 \\
\hline Average precentage & $88,23 \%$ \\
\hline
\end{tabular}

From the table 6 it is known that response to score students media developed.The chief rata-rata the percentage of the students $88,23 \%$ category in a very reasonable which means students respond very positive scrapbook media uses to the matter virus. Data survey motivation students before and after using media scrapbook seen in table 7.

Table 7 the score motivation students before and after using media scrapbook.

\begin{tabular}{lll} 
Statement & $\begin{array}{l}\text { Score } \\
\text { before using of } \\
\text { scrapbook }\end{array}$ & $\begin{array}{c}\text { student } \\
\text { of scrapbook }\end{array}$ \\
\hline 1 & 87 & 119 \\
\hline 2 & 93 & 127 \\
\hline 3 & 97 & 122 \\
\hline 4 & 90 & 128 \\
\hline 5 & 94 & 124 \\
\hline 6 & 89 & 120 \\
\hline
\end{tabular}


JOSAR, Vol. 1 No. 1 March, 2018; p-ISSN: 2502-8251; e-ISSN: 2503-1155

Copyrights@ Balitar Islamic University, Blitar-Indonesia

https://ejournal.unisbablitar.ac.id/index.php/josar

\begin{tabular}{lll}
\hline 7 & 92 & 109 \\
\hline 8 & 88 & 124 \\
\hline 9 & 89 & 134 \\
\hline 10 & 96 & 124 \\
\hline 11 & 95 & 108 \\
\hline 12 & 90 & 130 \\
\hline 13 & 90 & 130 \\
\hline 14 & 94 & 109 \\
\hline 15 & 91 & 124 \\
\hline 16 & 85 & 118 \\
\hline 17 & 93 & 109 \\
\hline 18 & 95 & 106 \\
\hline 19 & 104 & 125 \\
\hline 20 & 91 & 124 \\
\hline 21 & 97 & 127 \\
\hline 22 & 98 & 135 \\
\hline Total & 2038 & 2672 \\
\hline Criterion score & 3300 & 3300 \\
\hline Average & $61,75 \%$ & $80,96 \%$ \\
preventage & &
\end{tabular}

Based on the results of motivation table 7 watchful such provided to a student a class experiment, the score motivation students use increased by $19,21 \%$ scrapbook media .According to sardiman for 2010 , it can be said as a whole power motivation driving forces in on them that give rise to the activities of learning, so the purpose of is intended by the subject of learning can be achieved. The students are able motivated to learn because uses the media scrapbook. Based on such a motivation that has been filled by students it can be seen that most of the students after studying material virus with using scrapbook developed, putting students increase in every pernyataanya motivation

A score on the highest indicators to 4 and to 20 namely students love to work more independent and thrilled to find and solve problems. It is in a media scrapbook include the theory / material related to the virus as well as domestic knowledge common about the virus, so that in this case the media scrapbook had a role in order to clarify the matter of an 
abstracting nature and verbalistis to be able to easily understood by students. This is in accordance with the theory of usman (2002), who said that media can clarify and loosening the concept of complex and abstract into simpler ones.

Scrapbook media function in this case in accordance with statements from usman (2002), who said that the media can as the tools for learning activities of is the kingdom of visual lessons to students in order to the motivation to study, clarify, and loosening the concept of complex and abstract into simpler ones, concrete and easy to understand so can increase the motivation to study students.

\section{CONCLUSIONS AND SUGGESTIONS}

Based on the results of research and discussion it can be concluded that the assessment results of the the $80,06 \%$ with noncompetitive purchase will be criteria it is very appropriate. This result indicates that scrapbook media on any material a virus to basically class $x$ high school developed by researchers expressed it is very appropriate for use in learning. An increase in the score motivation as much as $19,21 \%$ after uses the media scrapbook. The experimental work on there are many things, so that researchers for any other researcher who wish to complete scrapbook media for committing to the next Stage to the stages of that is spreading in addition to ten, researchers is expected to develop scrapbook media that includes material in addition to the topic the virus.

\section{REFRENCES}

Arsyad a. 2003. Learning Media. Jakarta.: PT The king grafindo.

Astuti ap. 2013. An increase in scrapbook skills posters use a theme of conservation culture .A JOURNAL UNS 16 (1):1-14.

Haryaneu y. 2015. Evektivitas scrapbook media uses to enhance the capacity of writing a wreath of a description of. A JOURNAL UPI 3 ( 1): 1-14. 
JOSAR, Vol. 1 No. 1 March, 2018; p-ISSN: 2502-8251; e-ISSN: 2503-1155

Copyrights@ Balitar Islamic University, Blitar-Indonesia

https://ejournal.unisbablitar.ac.id/index.php/josar

Irmayanti s. 2016. So for the development of web-based media blog to increase the motivation to study students. EDUCATION JOURNAL 3 (1): 1-12.

Sari Ik. 2018. The influence of the media scrapbook of the results of learning ipa matter a source of energy a student of class iv sdn the tongue kulon iv surabaya. A JOURNAL STUDENTS 6 (5): 693-702.

Subardi et al. 2009. Biology to a class $x$ high school and MA Jakarta: Cv. Business prosperous.

.Sudirman u.s. . 2012. Learning Media. Jakarta: PT king grafindo persada.

Sugiyono. 2015. In the methodology education: a quantitative approach , qualitative , and R \& D. Bandung: Alfabeta.

Usman b, aswir. 2002 .Media . Jakarta. PT Intermasa.

Putri LS. 2014. Make software design cover scrapbook for adult. JURNAL ILMIAH MAHASISA UNIVERSITAS SURABAYA 3(1): 1-6. 